\title{
STRES DAN GEJALA DISPEPSIA FUNGSIONAL PADA REMAJA
}

\author{
Intan Sari Putri ${ }^{1}$, Widyatuti ${ }^{2} *$ \\ ${ }^{1}$ Program Studi Sarjana Fakultas Ilmu Keperawatan, Universitas Indonesia \\ ${ }^{2}$ Departemen Keperawatan Komunitas Fakultas Ilmu Keperawatan, Universitas Indonesia \\ *tuticw@yahoo.com
}

\begin{abstract}
ABSTRAK
Remaja merupakan populasi yang berisiko mengalami berbagai permasalahan kesehatan, salah satunya gejala dispepsia fungsional. Stres menjadi salah satu penyebab munculnya permasalahan kesehatan pada remaja seiring perubahan dalam perkembangannya. Penelitian ini bertujuan untuk mengidentifikasi hubungan antara stres dan gejala dispepsia fungsional pada remaja SMA. Desain penelitian ini yaitu cross-sectional dengan 360 responden dipilih melalui metode purposive sampling dan stratified-cluster sampling dari SMA di kota Bekasi. Instrumen penelitian ini yaitu the shortened version of the adolescent stress questionnaire (ASQ-S) dan dyspepsia symptom severity index (DSSI). Hasil penelitian menunjukkan mayoritas remaja SMA lebih adaptif terhadap stres dan tidak merasakan gejala dispepsia. Hasil penelitian menggunakan uji Chi-square didapatkan hubungan yang signifikan antara stres dan gejala dispepsia fungsional pada remaja dengan nilai $\mathrm{p}$ sebesar 0.001 . Hasil uji Odd Ratio (OR) didapatkan pada remaja yang merasakan stres berpeluang merasakan gejala dispepsia sebanyak 5,43 kali dibandingkan yang adaptif terhadap stres. Pelaksanaan pendidikan keterampilan hidup sehat dan pelayanan kesehatan mental berbasis sekolah diperlukan sebagai upaya untuk mengurangi stres pada remaja. Selain itu, diperlukan upaya kesehatan sekolah terkait nutrisi pada remaja melalui konseling nutrisi dan pendidikan kesehatan tentang pola makan yang teratur untuk meminimalisasi gejala dispepsia fungsional.
\end{abstract}

Kata kunci: gejala dispepsia fungsional, pelayanan kesehatan mental berbasis sekolah, pendidikan keterampilan hidup sehat, remaja, stres

\section{STRESS AND FUNCTIONAL DYSPEPSIA SYMPTOMS IN ADOLESCENTS}

\begin{abstract}
The population of adolescents is at risk of experiencing various health problems, one of the problems is the functional dyspepsia symptom. One of the causes of this health problem is stress, which changes in their development. The research aims to identify the relationship between stress and functional dyspepsia symptoms in high school adolescents. The research design used is cross-sectional with 360 respondents selected through purposive sampling method and stratified-cluster sampling taken from A High School in Bekasi City. The research instruments used were the shortened version of the adolescent stress questionnaire (ASQ-S) and dyspepsia severity index symptoms (DSSI). The results showed the majority of high school adolescents were more adaptive to stress and didn't feel dyspepsia symptoms. The results of the study were analyzed using the Chi-square test showed that there was a significant relationship between stress and functional dyspepsia symptoms in adolescents with a pvalue $=0.001$. The result of the Odd Ratio test $(O R)$ that is adolescents who feel stress has a chance of 55.72 times feeling dyspeptic symptoms compared to adolescents who are more adaptive to stress. The implementation of healthy life skills education and school-based mental health services are needed as an effort to reduce stress in adolescents. Moreover, a school health program related to nutrition is needed in adolescents through nutrition counseling and health education about regular eating patterns to minimize symptoms of functional dyspepsia.
\end{abstract}

Keywords: the functional dyspepsia symptom, school-based mental health services, healthy life skills education, adolescent; stress 


\section{PENDAHULUAN}

Masa remaja merupakan tahapan kehidupan yang pasti dilalui oleh setiap orang. Jumlah penduduk di Indonesia pada tahun 2017 yaitu sekitar 261 juta jiwa dan sekitar 16 juta jiwanya berada di provinsi Jawa Barat. Sebanyak 3 juta jiwa dari 14 juta penduduk berusia 15-19 tahun yang berada di Jawa Barat (Badan Pusat Statistik Indonesia [BPSStatistics Indonesia], 2018). Menurut Dinkes, kontribusi pelajar berusia remaja terbesar di Jawa Barat berada di kota Bekasi yaitu sekitar 86,3\% (Dinas Kesehatan Provinsi Jawa Barat, 2017). Tingginya populasi remaja di Indonesia diharapkan dapat menjadi aset dan penerus bangsa di masa yang akan datang. Namun untuk dapat mewujudkan harapan tersebut, masyarakat harus dapat menjamin agar remaja Indonesia tumbuh dan berkembang secara positif dan terbebas dari permasalahan yang mengancam, terutama dalam hal kesehatan misalnya stres. Perubahan dari segi fisik, psikososial, kognitif, dan moral dapat memicu munculnya konflik pada remaja (Berman, Snyder, \& Frandsen, 2016).

Konflik terhadap diri sendiri maupun orang lain, serta peristiwa negatif dapat menjadi stresor atau penyebab stres pada remaja (Shapero, 2015). Menurut WHO, sekitar 20\% remaja di dunia mengalami stres dan gangguan mental emosional setiap tahunnya (World Health Organization, 2014). Prevalensi stres dan gangguan mental emosional ringan di Indonesia sekitar 14 juta jiwa, sedangkan sekitar 400 ribu jiwa mengalami gangguan mental berat. Prevalensi stres pada remaja usia di atas 15 tahun mencapai 6\% (Kementerian Kesehatan Republik Indonesia, 2016).

Mekanisme tubuh seseorang yang sedang mengalami stres dimulai dengan peranan sistem biologis tubuh yaitu sistem saraf otonom dan aksis hypothalamic-pituitaryadrenal (HPA) pada otak (Shapero, 2015). Sebuah penelitian menghasilkan sebuah fakta bahwa remaja akan lebih rentan terhadap stres (Romeo, 2013). Hal tersebut karena adanya pematangan saraf berkelanjutan otak pada daerah limbik dan kortikal yang menghasilkan perubahan yang signifikan dalam aksis HPA sehingga meningkatkan sensitivitas saraf otak terhadap respon stres sementara respon remaja yang masih labil terhadap stresor. Regulasi neuroendrokrin akibat adanya stresor menghasilkan hormon kortisol dapat memunculkan respon fisiologis dan adaptif terhadap stresor. Akan tetapi, jika otak sangat sensitif terhadap stresor dan sering terpapar dalam jangka waktu yang lama maka dapat terjadi respon maladaptif (Romeo, 2013). Sistem saraf simpatik menurunkan kerja sistem gastrointestinal ketika tubuh terpapar stresor sementara asam lambung yang terus diproduksi pada proses pencernaan yang lamban dapat menyebabkan produksi asam lambung berlebih.

Model psikososial Holmes dan Rahe tahun 1975 menyebutkan bahwa stres sebagai suatu stimulus atau penyebab adanya respons (Smeltzer, Bare, Hinkle, \& Cheever, 2010). Model ini mengaitkan stres sebagai faktor penyebab yang meningkatkan kepekaan individu terhadap penyakit. Hal ini berarti semakin individu terpapar oleh stres maka semakin rentan individu terhadap suatu penyakit. Stres dapat mengakibatkan berbagai gangguan gastrointestinal, salah satunya dispepsia yang merupakan sekelompok gejala sistem pencernaan bagian atas yang berjadi karena berbagai faktor (Lee, Lee, Kim, \& Cho, 2009). Gejala yang terjadi meliputi rasa sakit, perasaan terbakar ataupun rasa tidak nyaman pada abdomen bagian atas, serta perasaan cepat kenyang dan penuh yang tidak nyaman setelah makan (National Institute of Diabetes and Digestive and Kidney Disease [NIDDK], 2016). Faktor yang berkontribusi dalam terjadinya dispepsia ini, antara lain gaya hidup yang tidak sehat (misalnya konsumsi makanan pedas dan mengandung asam berlebih atau konsumsi minuman beralkohol dan mengandung kafein berlebih), stres, merokok, infeksi $H$. Pylori, penggunaan obat (misalnya NSAIDs), serta memiliki masalah kesehatan atau penyakit saluran pencernaan (Kumar, Patel, \& Sawant, 2012). Penelitian oleh Bennett tahun 1990 menunjukkan bahwa pasien dengan dispepsia fungsional melaporkan lebih banyak life stress dan tekanan psikologis daripada kontrol yang sehat (Lee et al., 2009).

Prevalensi dispepsia pada beberapa negara bervariasi, yaitu 34,2 persen di Selandia Baru, 30,4 persen di India, 23-25,8 persen di Amerika Serikat, 14,5 persen di Skandinavia, dan 7-8 persen di Singapura (Lee et al., 2009). Di Indonesia, dispepsia merupakan penyakit urutan kelima dari sepuluh besar penyakit terbanyak pada tahun 2010 (Kementerian 
Kesehatan Republik Indonesia, 2011). Jumlah Kasus dispepsia di kota Bekasi tahun 2014 yaitu sekitar 25584 kasus dinilai lebih tinggi dibanding kota lainnya di Jawa Barat (Dinas Kesehatan Kota Bekasi, 2014). Data dari puskesmas di kota Bekasi tahun 2014 menunjukkan sekitar 4712 kasus baru dispepsia yang di derita oleh pasien rawat jalan berusia 15 tahun ke atas. Sebuah penelitian menyebutkan bahwa dispepsia menempati peringkat keenam keluhan pasien rawat jalan di RS Indonesia (Simadibrata \& Adiwinata, 2017). Penelitian lain juga menggambarkan prevalensi dispepsia fungsional sebagai peringkat keenam penyakit pada pasien rawat jalan di RS Cipto Mangunkusumo sepanjang tahun 2010 yaitu sebanyak $4,7 \%$ dari 904 sampel (Omega, 2013).

Kasus dispepsia pada remaja dapat memengaruhi kualitas hidup remaja (National Institute of Diabetes and Digestive and Kidney Disease [NIDDK], 2016). Penurunan produktivitas sehari-hari, misalnya tidak masuk sekolah akibat gejala yang telah disebutkan sebelumnya dapat menurunkan kualitas belajar pada remaja. Sementara itu, kualitas belajar yang menurun dapat menurunkan prestasi belajar siswa. Lamakelamaan, hal ini dapat berdampak pada menurunnya mutu siswa sebagai sumber daya manusia dan generasi penerus bangsa di masa akan datang (Kementerian Kesehatan Republik Indonesia, 2019). Selain itu, perilaku tidak mampu menghabiskan makanan dengan porsi yang biasanya karena rasa nyeri dapat mengakibatkan permasalahan gizi pada remaja kedepannya misalnya anemia. Kekurangan zat besi pada remaja putri berdampak sangat serius di masa depan (Kementerian Kesehatan Republik Indonesia, 2018). Hal ini karena remaja putri merupakan calon ibu dan melahirkan bayi sehingga dapat meningkatkan risiko kematian ibu melahirkan. Suatu penelitian juga mengemukakan hal yang sama, bahkan permasalahan gizi pada ibu hamil akan meningkatkan risiko kelahiran bayi prematur dan berat badan lahir rendah (Branca, Piwoz, Schultink, \& Sullivan, 2015). Selain anemia, permasalahan gizi remaja lebih lanjut dapat berdampak pada peningkatan penyakit menular dan tidak menular (World Health Organization, UNICEF, \& World Food Programme, 2014).

Penanganan masalah kesehatan remaja telah dicanangkan oleh pemerintah Indonesia melalui pelaksanaan pendidikan keterampilan hidup sehat (PKHS) (Kementerian Kesehatan RI, 2019). Upaya pemberdayaan remaja dalam menghadapi tantangan hidup ini memerlukan keterlibatan dari berbagai pihak. Selain itu, diperlukan panduan keselamatan komunitas sebagai upaya pelayanan kesehatan mental berbasis sekolah (Keliat et al., 2014). Latihan pertahanan diri terhadap stres merupakan kegiatan melatih keterampilan koping remaja dalam mengontrol stres. Pada realitanya, berbagai upaya tersebut belum diterapkan pada beberapa sekolah di Indonesia (Badan Litbangkes Kementerian Kesehatan Republik Indonesia, 2015). Padahal jika upaya tersebut berhasil diaplikasikan sangat bermanfaat untuk mengurangi stres pada remaja yang secara tidak langsung pula dapat meminimalisasi gejala dispepsia fungsional pada remaja. Selain itu, karena faktor gaya hidup terutama nutrisi menjadi faktor yang berkontribusi dalam terjadinya dispepsia ini maka diperlukan pemanfaatan program Upaya Kesehatan Sekolah (UKS) terkait nutrisi. Sejauh ini belum ada penelitian tentang kesehatan remaja di kota Bekasi, khususnya mengenai stres dan dispepsia. Berbagai fenomena di atas membuat peneliti tertarik untuk melakukan penelitian terkait stres dan gejala dispepsia fungsional pada remaja. Tujuannya dari penelitian ini yaitu untuk mengidentifikasi hubungan antara stres dan gejala dispepsia fungsional pada remaja melalui penelitian kuantitatif.

\section{METODE}

Jenis penelitian ini merupakan penelitian deskriptif-analitik (korelasional) dengan desain penelitian studi cross sectional. Populasi target pada penelitian ini yakni remaja kelas $\mathrm{X}$ dan XI di kota Bekasi, sedangkan populasi terjangkaunya remaja di dua SMA yang berakreditasi A tahun 2017/2018 di kota Bekasi yang berjumlah 1470 orang. Tempat penelitian ini yaitu dua sekolah menengah atas (SMA) di kota Bekasi yang berakreditasi A pada tahun 2017/2018. Sekolah yang berakreditasi A dapat diasumsikan bahwa prestasi dari siswa-siswinya sangatlah baik. Selain itu, mereka cenderung lebih belajar dengan giat dan memiliki stres yang lebih tinggi dibandingkan dengan sekolah lainnya. Kedua sekolah tersebut dipilih secara acak dari sekolah-sekolah yang ada pada 12 kecamatan di kota Bekasi. 
Kriteria inklusi dalam penelitian ini yaitu remaja kelas $\mathrm{X}$ dan XI di SMAN 8 Kota Bekasi dan SMAN 3 Kota Bekasi yang berstatus aktif, sedangkan kriteria eksklusinya yaitu remaja atau siswa yang sedang sakit (misalnya pusing dan sakit kepala sehingga tidak dapat berkonsentrasi untuk mengisi kuesioner, serta yang didiagnosis oleh dokter menderita penyakit ulkus peptikum, gastritis, atau kanker abdomen. Pada penelitian ini pemilihan sampel dilakukan melalui teknik purposive dan stratified-cluster sampling kemudian dihitung menggunakan rumus Slovin, sehingga didapatkan sebanyak 360 sampel dalam penelitian ini. Peneliti telah memperoleh Surat Keterangan Lolos Kaji Etik dari Komite Etik Penelitian, Fakultas Ilmu Keperawatan Universitas Indonesia dengan Nomor:

SK233/UN2.F12.D1.2.1./ETIK.FIK.2019 sebagai bukti kelayakan penelitian.

Penelitian ini menggunakan alat ukur berupa kuesioner. Kuesioner bagian 1 mengenai informasi umum responden yang terdiri atas inisial nama, usia, jenis kelamin, dan jumlah kegiatan yang diikuti di luar jam sekolah. Kuesioner bagian 2 mengidentifikasi stres pada responden menggunakan the shortened version of the adolescent stress questionnaire (ASQ-S) berjumlah 27 pertanyaan (Anniko, Boersma, Wijk, Byrne, \& Tillfors, 2018). Instrumen ini telah diterjemahkan ke dalam Bahasa Indonesia, serta dilakukan uji validitas dan reliabilitasnya pada 30 remaja dengan hasil $r=$
0,317-0,655 dan nilai Cronbach's Alpha sebesar 0,737. Kuesioner bagian 3 mengidentifikasi gejala dispepsia fungsional pada responden menggunakan dyspepsia symptom severity index (DSSI) yang berjumlah 20 pertanyaan (Leidy, Farup, Rentz, Ganoczy, \& Koch, 2000; Tytgat \& Tytgat, 2008). Instrumen ini telah diterjemahkan ke dalam Bahasa Indonesia, serta dilakukan uji validitas dan reliabilitasnya pada 30 remaja dengan hasil $\mathrm{r}=0,368-0,767$ dan nilai Cronbach's Alpha sebesar 0,743 . Peneliti kembali melakukan uji validitas dan reliabilitas pada 30 remaja atau siswa SMAN 2 Kota Bekasi yang berbeda setelah memodifikasi sebuah pernyataan yang tidak valid. Uji validitas ASQ-S didapatkan $\mathrm{r}=$ 0,378-0,658 dan reabilitas Cronbach's Alpha sebesar 0,916, sedangkan kuesioner DSSI didapatkan hasil $\mathrm{r}=0,368-0,750$ dan reabilitas Cronbach's Alpha sebesar 0,931.

\section{HASIL}

Hasil dari penelitian ini dianalisis secara univariat dan bivariat. Analisis data univariat dilakukan untuk mendeskripsikan karakteristik remaja SMA, seperti, usia, jenis kelamin, jumlah kegiatan, stres pada remaja SMA, dan gejala dispepsia fungsional pada remaja SMA. Analisa data bivariat dilakukan untuk mendeskripsikan hubungan antara variabel stres dan gejala dispepsia fungsional. Karakteristik remaja SMA berdasarkan usia dapat dilihat pada tabel 1 .

Tabel 1.

Usia remaja SMA $(n=360)$

\begin{tabular}{cccc}
\hline Variabel & Mean & SD & Min - Maks \\
\hline Usia & 16,02 & 0,672 & $15-17$ \\
\hline
\end{tabular}

Berdasarkan tabel 1 dapat diketahui bahwa rata-rata usia remaja SMA adalah 16,02 tahun. Adapun standar deviasi usia remaja SMA sebesar 0,672. Hal ini berarti remaja yang menjadi responden di SMA terpilih memiliki usia yang hampir sama. Rentang usia remaja SMA pada penelitian ini yaitu 15-17 tahun. Karakteristik remaja SMA berdasarkan jenis kelamin dan jumlah kegiatan yang diikuti di luar jam sekolah dapat dilihat pada tabel 2 .

Tabel 2.

Jenis kelamin dan jumlah kegiatan remaja SMA $(n=360)$

\begin{tabular}{lcc}
\hline \multicolumn{1}{c}{ Karakteristik } & $\mathrm{f}$ & $\%$ \\
\hline Jenis Kelamin & & \\
Laki-laki & 161 & 44,7 \\
Perempuan & 199 & 55,3 \\
\hline Jumlah Kegiatan & & \\
Tidak ada & 89 & 24,7 \\
$1-2$ buah & 219 & 60,8 \\
$>2$ buah & 52 & 14,4 \\
\hline
\end{tabular}


Berdasarkan tabel 2, didapatkan proporsi remaja SMA dengan jenis kelamin perempuan lebih banyak dibanding laki-laki. Sebanyak 161 remaja SMA $(44,7 \%)$ berjenis kelamin perempuan dan sebanyak 199 remaja SMA $(55,3 \%)$ berjenis kelamin laki-laki. Berdasarkan jumlah kegiatan, paling banyak remaja SMA mengikuti kegiatan di luar jam sekolah sebanyak 1 atau lebih $(75,2 \%)$. Hal ini menunjukkan hanya sedikit remaja SMA yang tidak memiliki kegiatan. Selanjutnya kondisi stres dan gejala dispepsia fungsional remaja SMA dapat dilihat di tabel 3.

Tabel 3.

Kondisi stres dan gejala dispepsia fungsional pada remaja SMA $(n=360)$

\begin{tabular}{lrl}
\hline \multicolumn{1}{c}{ Variabel } & F & $\%$ \\
\hline Kondisi Stres & & \\
Stres & 170 & 47,2 \\
Adaptif & 190 & 52,8 \\
\hline Gejala Dispepsia Fungsional & 174 & 48,3 \\
$\begin{array}{l}\text { Dispepsia } \\
\text { Tanpa dispepsia }\end{array}$ & 186 & 51,7 \\
Berdasarkan tabel 3, didapatkan proporsi & walaupun perbedaannya hanya 3,4\%. Hal ini \\
remaja SMA yang adaptif terhadap stres lebih & $\begin{array}{l}\text { menunjukkan kondisi remaja lebih banyak } \\
\text { banyak dibanding dengan remaja yang }\end{array}$ & $\begin{array}{l}\text { yang sehat dibandingkan yang memiliki gejala } \\
\text { mengalami stres, namun perbedaanya tidak }\end{array}$ \\
terlalu besar (5,6\%). Berdasarkan gejala & $\begin{array}{l}\text { dispepsia. Hubungan stres dan gejala dispepsia } \\
\text { dispepsia fungsional, paling banyak remaja remaja SMA ditampilkan pada }\end{array}$ \\
tabel 4.
\end{tabular}

Tabel 4.

Hubungan stres dan gejala dispepsia fungsional pada remaja SMA(n=360)

\begin{tabular}{|c|c|c|c|c|c|c|c|c|c|}
\hline \multirow{3}{*}{ Kondisi } & \multicolumn{4}{|c|}{ Gejala Fungsional } & \multirow{2}{*}{\multicolumn{2}{|c|}{ Total }} & \multirow{3}{*}{$x^{2}$} & \multirow{3}{*}{$P$ value } & \multirow{3}{*}{ OR $(95 \% C I)$} \\
\hline & \multicolumn{2}{|c|}{ Dispepsia } & \multicolumn{2}{|c|}{ Tanpa dispepsia } & & & & & \\
\hline & $\mathrm{f}$ & $\%$ & $\mathrm{f}$ & $\%$ & $\mathrm{f}$ & $\%$ & & & \\
\hline Stres & 118 & 32,8 & 52 & 14,4 & 170 & 47,2 & \multirow{3}{*}{55,72} & \multirow{3}{*}{0,001} & \multirow{3}{*}{$\begin{array}{c}5,43 \\
(3,458-8,527)\end{array}$} \\
\hline Adaptif & 56 & 15,6 & 134 & 37,2 & 190 & 52,8 & & & \\
\hline Total & 174 & 43,3 & 186 & 51,7 & 360 & 100 & & & \\
\hline
\end{tabular}

Berdasarkan tabel 4, didapatkan sekitar 32,8\% remaja menimbulkan semakin besar peluang remaja SMA yang mengalami stres juga merasakan gejala dispepsia. Sebaliknya, sekitar $37,2 \%$ remaja lebih adaptif terhadap stres tidak merasakan gejala dispepsia. Hal ini berarti bahwa remaja yang adaptif tanpa dispepsia lebih tinggi presentasenya dibandingkan yang stres dan mengalami dispepsia. Hasil uji statistik didapatkan nilai $x^{2}$ sebesar 55,72 sehingga ditemukan adanya hubungan yang signifikan antara stres dan gejala dispepsia fungsional pada remaja SMA dengan nilai $p$ sebesar $0,001(<0.05)$. Hasil uji Odd Ratio (OR) sebesar 5,43 sehingga dapat dikatakan bahwa remaja yang stres berpeluang 5,43 kali merasakan gejala dispepsia dibandingkan remaja yang adaptif. Hal ini berarti bahwa kemampuan adaptasi remaja berhubungan dengan munculnya gejala dispepsia fungsional sehingga semakin stres

\section{PEMBAHASAN}

\section{Gejala dispepsia fungsional pada remaja SMA}

Hasil penelitian ini menunjukkan remaja SMA lebih banyak yang sehat atau tidak merasakan gejala dispepsia. Penelitian ini didukung oleh beberapa penelitian yang menggunakan desain yang sama. Diantaranya hasil penelitian mahasiswa kedokteran Universitas Sumatera Utara yang menunjukkan hanya sekitar $24,4 \%$ dan $5,6 \%$ remaja mengalami gejala dispepsia sedang hingga berat, sedangkan sekitar 33,3\% dan $36,7 \%$ remaja mengalami gejala dispepsia ringan bahkan tidak ada gejala (Siregar, Halim, \& Sitepu, 2016). Hasil penelitian pada mahasiswa kedokteran Universitas Sumatera Utara berusia remaja akhir juga menunjukkan 
hasil yang hampir sama, yaitu sekitar 18,8\% remaja yang mengalami dispepsia, sedangkan $81,2 \%$ lainnya tidak mengalami dispepsia (Wirawan, 2015). Dari 100 mahasiswa yang diteliti tersebut juga ditemukan lebih banyak kejadian dispepsia pada remaja perempuan daripada laki-laki.

Penelitian lain yang dilakukan pada mahasiswa kedokteran Universitas Diponegoro yang menunjukkan hasil yang serupa dengan peneliti, yaitu ditemukan kejadian dispepsia fungsional sebesar 2,4\% (Rachmaputri \& Kusumawati, 2015). Dari 210 remaja di Semarang yang diteliti, ditemukan juga lebih banyak kejadian dispepsia fungsional pada remaja perempuan daripada laki-laki. Tidak hanya pada remaja, gejala dispepsia fungsional pada dewasa juga sebagian besar dialami oleh perempuan. Hal ini dibuktikan dengan penelitian pada pasien dewasa yang mengalami dispepsia di poliklinik penyakit dalam RSUD Wangaya Denpasar tahun 2018 yang menyebutkan bahwa persentase dispepsia fungsional pada perempuan lebih banyak dibanding pada laki-laki yaitu 56,3\% dibanding 43,7\% (Ratnadewi \& Lesmana, 2018).

Hasil penelitian dengan responden mahasiswa STIKes Sumbar berusia remaja akhir juga menunjukkan hasil yang hampir sama dengan peneliti yaitu didapatkan sebagian remaja mengalami dispepsia fungsional dan sebagian lagi tidak mengalaminya (Chaidir \& Maulina, 2015). Kelima penelitian terhadap dispepsia fungsional ini menunjukkan hasil yang hampir mirip dengan peneliti. Perbedaannya hanya sedikit yang terletak pada persentase gejala dispepsia fungsional. Hal ini terjadi karena perbedaan usia responden, jumlah responden, jumlah institusi, dan instrumen penelitian yang digunakan.

Berdasarkan hasil penelitian yang telah dilakukan peneliti, gejala yang paling sering dirasakan oleh responden yaitu merasa cepat kenyang setelah makan $(8,89 \%)$. Perasaan cepat kenyang setelah makan termasuk ke dalam manifestasi klinis dispepsia fungsional yang dinamakan early satiation. Berdasarkan Kriteria Diagnostik Roma IV, early satiation merupakan perasaan abdomen yang terlalu penuh segera setelah memulai makan, tidak sesuai dengan ukuran makanan yang dimakan sehingga makan tidak dapat diselesaikan (Stanghellini, 2017). Gejala ini merupakan gejala dismotilitas atau gangguan motilitas pada lambung saat terjadi penurunan aliran darah ke lambung. Hal ini terjadi karena produksi asam lambung yang berlebih sehingga dapat menghambat akomodasi lambung setelah makan. Penundaan pengosongan pada lambung juga dapat menyebabkan munculnya gejala mual walau keadaan lambung sedang tidak diisi makanan. Gejala mual pada pagi hari ketika lambung sedang tidak diisi makanan menjadi gejala yang jarang ditemukan pada responden $(2,22 \%)$. Penelitian menyebutkan bahwa hanya beberapa pasien dispepsia fungsional yang mengeluh adanya mual dan muntah. Sebanyak $5-11 \%$ pasien merasakan early satiation yang merupakan persentase gejala yang sering dikeluhkan pada pasien dispepsia fungsional (Talley, Goodsall, \& Potter, 2017).

Produksi asam lambung yang berlebih dapat terjadi karena berbagai hal, seperti pola makan yang teratur dan stres (Kumar et al., 2012). Melalui program UKS terkait nutrisi seperti konseling dan pendidikan kesehatan, gejala dispepsia fungsional dapat diminimalisasi. Misalnya, remaja dapat diberikan pendidikan kesehatan tentang pentingnya pola makan yang teratur, bahaya konsumsi makanan pedas dan mengandung asam berlebih, serta bahaya konsumsi minuman beralkohol dan mengandung kafein berlebih terhadap kesehatan.

\section{Stres pada remaja SMA}

Hasil penelitian ini menunjukkan bahwa proporsi remaja SMA yang lebih adaptif terhadap stres lebih banyak dibanding dengan remaja yang mengalami stres. Penelitian ini didukung sebuah penelitian yang menggunakan desain yang sama. Hasil penelitian dengan responden mahasiswa STIKes Sumbar berusia remaja akhir tersebut menunjukkan hanya sebagian kecil saja remaja yang mengalami stres sedang $(30 \%)$ dan berat (7,5\%), sedangkan sekitar $25 \%$ dan $37,5 \%$ remaja lainnya hanya mengalami stres ringan bahkan tidak mengalami stres (Chaidir \& Maulina, 2015). 
Hasil penelitian yang tidak mendukung didapatkan dari penelitian yang dilakukan pada remaja SMA di Manado dengan hasil persentase remaja SMA mengalami stres sebanyak $80,3 \%$, sedangkan remaja yang tidak mengalami stres sebanyak 19,7\% (Saroinsong, Palandeng, \& Bidjuni, 2014). Perbedaan ini dapat terjadi karena penelitian tersebut hanya melibatkan 61 responden yang berasal dari satu sekolah sekolah, sedangkan penelitian peneliti melibatkan 360 responden yang berasal dari dua sekolah yang dipilih secara acak dari satu kota dan memiliki karakteristik yang sama. Selain itu, responden pada penelitian yang dilakukan oleh Saroinsong, Palandeng dan Bidjuni (2014) ini, hanya melibatkan remaja kelas $\mathrm{X}$, lokasi berbeda dan menggunakan instrumen yang berbeda. Perbedaan ini memungkinkan adanya hasil yang diperoleh. Selain itu, karakteristik remaja mengalami perkembangan yang cepat dalam proses perubahannya sesuai dengan lingkungannya.

Masa remaja merupakan usia terjadinya perubahan dari segi fisik, psikososial, kognitif, dan moral. Berbagai konflik dalam kehidupan, stres, dan permasalahan yang tidak dapat ditangani oleh remaja dapat menyebabkan usia remaja berisiko terhadap berbagai permasalahan kesehatan (Healthy People 2020, 2019). Sebuah penelitian mengungkapkan bahwa remaja akan lebih rentan terhadap stres (Romeo, 2013). Hal tersebut karena adanya pematangan saraf berkelanjutan otak pada daerah limbik dan kortikal yang menghasilkan perubahan yang signifikan dalam aksis HPA sehingga dapat meningkatkan sensitivitas saraf otak terhadap respon stres sementara respon remaja yang masih labil terhadap stresor. Penelitian mahasiswa kedokteran Universitas Sumatera Utara menunjukkan bahwa stres pada remaja putri lebih besar daripada remaja putra (Siregar et al., 2016). Rudolph tahun 2002 berpendapat juga bahwa remaja putri sering terpapar peristiwa negatif dalam kehidupannya sehingga melaporkan lebih banyak stres daripada remaja putra (Shapero, 2015). Hal tersebut karena otak wanita lebih sensitif terhadap hormon yang dihasilkan saat tubuh terpapar stresor. Selain itu, sebuah penelitian menjelaskan bahwa hormon seks wanita yaitu estradiol dan progesteron dapat memengaruhi kemampuan otak untuk mengatasi stres, sehingga memperkuat respons stres pada otak (Li \& Graham, 2017).

Stres pada remaja dapat muncul karena kurangnya keterampilan psikososial remaja dalam menghadapi perubahan perkembangan dan situasi dalam kehidupannya. Berdasarkan hasil penelitian yang dilakukan peneliti, situasi dalam kehidupan remaja yang paling sering mengakibatkan stres pada responden yaitu karena terlalu banyak pekerjaan rumah (PR) yang diberikan sekolah $(16,67 \%)$. Situasi yang paling jarang menyebabkan stres pada responden yaitu ketika dirinya akrab dengan lawan jenis yang disukai $(0,83 \%)$. Hal ini terjadi karena secara perkembangan sosial, remaja cenderung mengalami ketertarikan terhadap lawan jenis sehingga apabila dirinya akrab terhadap lawan jenis yang disukai maka jarang menyebabkan stres pada remaja.

Terlalu banyaknya pekerjaan rumah (PR) yang diberikan sekolah termasuk ke dalam situasi di kehidupan remaja yang berkaitan dengan waktu luang. Situasi tersebut dapat menjadi stimulus kontekstual dalam teori Adaptasi Roy tahun 1980 (Potter, Perry, Stockert, \& Hall, 2013). Stimulus tersebut merupakan stimulus yang berkontribusi atau merupakan pencetus kesulitan tubuh dalam beradaptasi terhadap stresor pada masa remaja (Anniko, Boersma, \& Tillfors, 2019). Akan tetapi ketika remaja memiliki keterampilan psikososial yang baik, misalnya kemampuan dalam mengambil keputusan dan memecahkan masalah atau kemampuan mengatasi stres maka remaja lebih adaptif terhadap stres. Melalui pelaksanaan pendidikan keterampilan hidup sehat (PKHS), remaja dapat lebih mengenal dan mempraktikkan keterampilan psikososial untuk mengatasi stres. Selain keterampilan psikososial, diperlukan pula keterampilan koping yang konstruktif. Melalui pelayanan kesehatan mental berbasis sekolah (PKMBS), remaja dapat belajar mengontrol stres dengan berpikir positif dan melakukan hobi. Misalnya ketika terlalu banyak pekerjaan rumah (PR), remaja dapat berpikir lebih positif bahwa PR yang diberikan bertujuan agar mereka lebih terlatih dalam mengerjakan soal-soal sehingga menjadikan mereka lebih pintar. 


\section{Karakteristik remaja SMA}

Hasil penelitian ini menunjukkan remaja yang menjadi responden di SMA terpilih memiliki usia yang hampir sama. Rata-rata usia remaja SMA yaitu 16 tahun didukung hasil penelitian dengan menggunakan desain penelitian yang sama. Hasil penelitian pada remaja SMA di Manado tersebut menunjukkan bahwa mayoritas usia remaja SMA $(68,8 \%)$ yaitu 16 tahun (Saroinsong et al., 2014).

Hasil dari penelitian ini mengidentifikasi bahwa lebih dari setengah remaja SMA berjenis kelamin perempuan. Penelitian ini didukung oleh beberapa penelitian yang menggunakan desain penelitian yang sama. Diantaranya hasil penelitian dengan responden remaja SMA menunjukkan sekitar 52,5\% berjenis kelamin perempuan (Saroinsong et al., 2014). Penelitian dengan responden mahasiswa berusia remaja akhir juga menunjukkan hasil bahwa perempuan merupakan mayoritas jenis kelamin responden (Chaidir \& Maulina, 2015). Jumlah kegiatan yang diikuti di luar jam sekolah hanya sebagai gambaran banyaknya kegiatan yang dilakukan oleh remaja untuk menyalurkan bakat, bersosialisasi, dan mengisi waktu luang. Remaja yang tidak memiliki waktu luang untuk melakukan aktivitas yang diinginkan akan meningkatkan stres pada dirinya (Anniko et al., 2019). Terbukti dari hasil penelitian menunjukkan bahwa mayoritas remaja lebih adaptif terhadap stres karena hanya sedikit remaja SMA yang tidak memiliki kegiatan.

\section{Stres dan gejala dispepsia fungsional pada remaja SMA}

Hasil penelitian menunjukkan bahwa terdapat hubungan signifikan antara stres dan gejala dispepsia fungsional pada remaja SMA. Penelitian ini didukung oleh beberapa penelitian menggunakan desain penelitian yang sama. Diantaranya hasil penelitian pada responden mahasiswa STIKes Sumbar berusia remaja akhir yang menunjukkan adanya hubungan antara tingkat stres dan kejadian sindrom dispepsia fungsional (Chaidir \& Maulina, 2015). Penelitian dengan responden pasien dispepsia di Puskesmas Purwodiningratan Jebres Surakarta juga ditemukan adanya hubungan antara stres dengan kejadian dispepsia (Rahmaika, 2014). Kalimat akhir dari dua penelitian di atas menunjukkan bahwa ada hubungan antara stres dan kejadian dispepsia. Hal ini dapat terjadi karena adanya peranan sistem biologis tubuh ketika seseorang mengalami stres.

Sistem saraf otonom dan aksis HPA pada otak merupakan dua sistem biologis tubuh yang berperan ketika tubuh terpapar stresor (Chaidir \& Maulina, 2015). Sistem saraf otonom, lebih tepatnya sistem saraf simpatik merupakan respon kerja cepat dari stres yang mengaktifkan respon "fight or flight" dengan meningkatkan kerja sistem tubuh manusia, kecuali sistem gastrointestinal. Asam lambung yang terus diproduksi sementara proses pencernaan yang lamban akibat pengaruh sistem saraf simpatik dapat menyebabkan produksi asam lambung berlebih. Sebuah penelitian menunjukkan bahwa stres fisiologis dan psikologis dapat meningkatkan sekresi asam lambung dan pepsin sehingga akan menyebabkan perubahan nekrotik dan inflamasi pada lambung (Nabavizadeh, Adeli, Sahraei, \& Salimi, 2011). Hal tersebut dapat menjadikan stres sebagai faktor yang berkontribusi terhadap munculnya keluhan dispepsia. Selain stres, pola makan yang tidak teratur juga dapat menimbulkan gejala dispepsia fungsional pada remaja (Kumar et al., 2012).

\section{SIMPULAN}

Remaja berusia rata-rata 16 tahun dan berjenis kelamin perempuan. Hanya sedikit remaja yang tidak memiliki kegiatan. Proporsi remaja SMA yang adaptif terhadap stres lebih banyak dibanding dengan remaja SMA yang mengalami stres sehingga mayoritas remaja SMA lebih adaptif terhadap stres. Mayoritas remaja SMA juga lebih sehat atau tidak merasakan gejala dispepsia. Remaja yang merasakan stres berpeluang 5,43 kali merasakan gejala dispepsia dibandingkan remaja yang lebih adaptif terhadap stres.

\section{DAFTAR PUSTAKA}

Anniko, M. K., Boersma, K., \& Tillfors, M. (2019). Sources of stress and worry in the development of stress-related mental health problems: A longitudinal investigation from early- to midadolescence. Anxiety, Stress, \& Coping, $32 \quad(2)(2), \quad 155-167$. https://doi.org/10.1080/10615806.2018. 


\section{7}

Anniko, M. K., Boersma, K., Wijk, N. P. L. Van, Byrne, D., \& Tillfors, M. (2018). Development of a Shortened Version of the Adolescent Stress Questionnaire (ASQ-S): construct validity and sex invariance in a large sample of Swedish adolescents. Scandinavian Journal of Child and Adolescent Psychiatry and Psychology, 6(1 (July 2018)), 1-12. https://doi.org/10.21307/sjcapp-2018001

Badan Litbangkes Kementerian Kesehatan Republik Indonesia. (2015). Perilaku Berisiko Kesehatan Pada Pelajar SMP dan SMA di Indonesia: Hasil Survei Nasional Kesehatan Berbasis Sekolah di Indonesia. Jakarta: Pusat Teknologi Intervensi Kesehatan Masyarakat.

Badan Pusat Statistik Indonesia [BPS-Statistics Indonesia]. (2018). Statistik Indonesia 2018 [Statistical Yearbook of Indonesia 2018]. Jakarta: Badan Pusat Statistik Indonesia [BPS-Statistics Indonesia]. https://doi.org/03220.1811

Berman, A., Snyder, S. J., \& Frandsen, G. (2016). KOZIER \& ERB'S FUNDAMENTALS OF NURSING: Concepts, Process, and Practice (10th ed). United States of America: Pearson Education, Inc.

Branca, F., Piwoz, E., Schultink, W., \& Sullivan, L. M. (2015). Nutrition and health in women, children, and adolescent girls. British Medical Journal, 351(September), 4173. https://doi.org/http://dx.doi.org/10.1136/ bmj.h4173

Chaidir, R., \& Maulina, H. (2015). HUBUNGAN TINGKAT STRES DENGAN KEJADIAN SINDROM DISPEPSIA FUNGSIONAL PADA MAHASISWA SEMESTER AKHIR PRODI S1 KEPERAWATAN DI STIKES YARSI SUMBAR BUKITTINGGI. Jurnal Ilmu Kesehatan 'Afiyah, 2 (2), 1-6. Retrieved from http://ejournal.stikesyarsi.ac.id/index.ph p/JAV1N1/article/view/49
Dinas Kesehatan Kota Bekasi. (2014). Profil Kesehatan Kota Bekasi Tahun 2014. Bekasi: Dinas Kesehatan Kota Bekasi. Retrieved from http://www.depkes.go.id/resources/dow nload/profil/PROFIL_KAB_KOTA_201 4/3275_Jabar_Kota_Bekasi_2014.pdf

Dinas Kesehatan Provinsi Jawa Barat. (2017). Profil Kesehatan Provinsi Jawa Barat tahun 2016. Bandung: Dinas Kesehatan Provinsi Jawa Barat. Retrieved from http://diskes.jabarprov.go.id

Healthy People 2020. (2019). Office of Disease Prevention and Health Promotion: Adolescent health. Retrieved April 10, 2019, from https://www.healthypeople.gov/2020/top ics-objectives/topic/Adolescent-Health

Keliat, B. A., Handayani, H., Permatasari, H., Helena, N., Wanda, D., \& Tololiu, T. A. (2014). Panduan Keselamatan Komunitas pada Anak \& Remaja. Jakarta: Buku Kedokteran EGC.

Kementerian Kesehatan Republik Indonesia. (2011). Profil Kesehatan Indonesia 2010. Jakarta: Katalog Dalam Terbitan Kementerian Kesehatan RI. Retrieved from

http://www.depkes.go.id/resources/dow nload/pusdatin/profil-kesehatanindonesia/profil-kesehatan-indonesia2010.pdf

Kementerian Kesehatan Republik Indonesia. (2016). PERAN KELUARGA DUKUNG KESEHATAN JIWA MASYARAKAT. Kementerian Kesehatan Republik Indonesia 2016, p. 1. Retrieved from http://www.depkes.go.id/article/print/16 100700005/peran-keluarga-dukungkesehatan-jiwa-masyarakat.html

Kementerian Kesehatan Republik Indonesia. (2018). KENALI MASALAH GIZI YANG ANCAM REMAJA INDONESIA. Kementerian Kesehatan Republik Indonesia 2018, p. 1. Retrieved from http://www.depkes.go.id/article/print/18 051600005/kenali-masalah-gizi-yang- 
ancam-remaja-indonesia.html

Kementerian Kesehatan Republik Indonesia. (2019). Capai Bonus Demografi, Jangan Abaikan Kesehatan Mental Remaja. Kementerian Kesehatan Republik Indonesia 2019, p. 1. Retrieved from http://www.depkes.go.id/article/view/19 031900001/achieve-demographicbonuses-don-t-ignore-adolescentmental-health.html

Kumar, A., Patel, J., \& Sawant, P. (2012). Epidemiology of Functional Dyspepsia. Journal of Association of Physicians of India, 60(March), 9-12. Retrieved from Kumar, A., Patel, J., \& Sawant, P. (2012). Epidemiology of Functional Dyspepsia. Journal of Association of Physicians of India, (March 2012); Vol. 60; 9-11.

Lee, S. Y., Lee, K. J., Kim, S. J., \& Cho, S. W. (2009). Prevalence and Risk Factors for Overlaps between Gastroesophageal Reflux Disease , Dyspepsia , and Irritable Bowel Syndrome: A Population-Based Study. S. Karger AG, Basel: Digestion, 79(April), 196-201. https://doi.org/10.1159/000211715

Leidy, N. K., Farup, C., Rentz, A. M., Ganoczy, D., \& Koch, K. L. (2000). Patient-Based Assessment in Dyspepsia: Development and Validation of Dyspepsia Symptom Severity Index (DSSI). Digestive Disease and Sciences, 45 (6)(June), 1172-1173.

Li, S. H., \& Graham, B. M. (2017). Why are women so vulnerable to anxiety, traumarelated and stress-related disorders? The potential role of sex hormones. The Lancet Psychiatry, 4(1), 73-82. https://doi.org/10.1016/S22150366(16)30358-3

Nabavizadeh, F., Adeli, S., Sahraei, H., \& Salimi, E. (2011). Physical and psychological stress have similar effects on gastric acid and pepsin secretions in rat. Journal of Stress Physiology and Biochemistry, 7 (2)(October 2014), 164 174.

Retrieved from https://www.researchgate.net/publicatio n/228901098_Physical_and_psychologi cal_stress_have_similar_effects_on_gast ric_acid_and_pepsin_secretions_in_rat/1 ink/542be6fe0cf277d58e8a5147/downlo ad

National Institute of Diabetes and Digestive and Kidney Disease [NIDDK]. (2016). Health Information: Indigestion (Dyspepsia). Retrieved February 17, 2019, from https://www.niddk.nih.gov/healthinformation/digestivediseases/indigestion-dyspepsia/allcontent

Omega, A. (2013). Prevalensi dispepsia fungsional pada pasien dewasa di Rumah Sakit Cipto Mangunkusumo Jakarta pada tahun 2010 dan faktor faktor yang berhubungan. Universitas Indonesia.

Potter, P. A., Perry, A. G., Stockert, P. A., \& Hall, A. M. (2013). FUNDAMENTALS OF NURSING (8th ed). St. Louis, Missouri: Elsevier Mosby.

Rachmaputri, J., \& Kusumawati, N. R. D. (2015). Hubungan antara Dispepsia Fungsional dengan Ansietas dan Depresi pada Remaja di Semarang. Media Medika Muda - Jurnal Kedokteran Diponegoro, 4 (4)(Oktober), 10491061.

Rahmaika, B. D. (2014). Hubungan Antara Stres Dengan Kejadian Dispepsia Di Puskesmas Purwodiningratan Jebres Surakarta. Universitas Muhammadiyah Surakarta. Retrieved from http://eprints.ums.ac.id/28100/

Ratnadewi, N. K., \& Lesmana, C. B. J. (2018). Hubungan strategi coping dengan dispepsia fungsional pada pasien di poliklinik penyakit dalam rumah sakit umum daerah wangaya denpasar. MEDICINA, 49 (2)(August), 257-262. https://doi.org/10.15562medicina.v49i2. 52

Romeo, R. D. (2013). The Teenage Brain: The Stress Response and the Adolescent 
Brain. Current Directions in Psychological Science, 22(2), 140-145. https://doi.org/10.1177/0963721413475 445

Saroinsong, M., Palandeng, H., \& Bidjuni, H. (2014). HUBUNGAN STRES DENGAN KEJADIAN GASTRITIS PADA REMAJA KELAS XI IPA DI SMA NEGERI 9 MANADO. Jurnal Keperawatan, 2 (2), 1-6. Retrieved from https://ejournal.unsrat.ac.id/index.php/jk p/article/view/5253/4766

Shapero, B. G. (2015). STRESS REACTIVITY AND COGNITIVE VULNERABILITY FOR DEPRESSION IN ADOLESCENCE. Temple University.

Simadibrata, M., \& Adiwinata, R. (2017). Current Issues of Gastroenterology in Indonesia. Acta Medica Indonesiana:The Indonesia Journal of Internal Medicine, 49 (3)(July), 270278.

Siregar, G. A., Halim, S., \& Sitepu, R. R. (2016). Dyspepsia and Depression, Anxiety, Stress Scales (DASS) Score. The Indonesian Journal of Gastroenterology, Hepatology and Digiestive Endoscopy, 17 (1)(April), 2831. https://doi.org/10.24871/17120162831

Smeltzer, S. C., Bare, B. G., Hinkle, J. L., \& Cheever, K. H. (2010). BRUNNER \& SUDDARTH'S Textbook of Medical Surgical Nursing (12th ed). Philadelphia, PA: Wolters Kluwer Health/ Lippincott Williams \& Wilkins.

Stanghellini, V. (2017). Functional Dyspepsia and Irritable Bowel Syndrome: Beyond Rome IV. Digestive Diseases 2017-S. Karger AG, Basel, 35(February 2018), 14-17.

https://doi.org/10.1159/000485408

Talley, N. J., Goodsall, T., \& Potter, M. (2017). Functional dyspepsia. Australian Prescriber, 40 (6)(Desember 2017), 209-213.

https://doi.org/10.18773/austprescr.2017 .066
Tytgat, G. N. J., \& Tytgat, S. H. A. J. (2008). Grading and Staging in Gastroenterology. Georg Thieme Verlag $K G$.

Wirawan, D. A. (2015). PERBANDINGAN KUALITAS HIDUP PENDERITA DISPEPSIA DENGAN NONDISPEPSIA PADA MAHASISWA FK $U S U$. Universitas Sumatera Utara.

World Health Organization. (2014). 10 FACTS ON MENTAL HEALTH. World Health Organization 2014, p. 1. Retrieved from https://www.who.int/features/factfiles/m ental_health/mental_health_facts/en/

World Health Organization, UNICEF, \& World Food Programme. (2014). WHA Global Nutrition Targets 2025 : Wasting Policy Brief. World Health Organization 2014 , p. 8 . Retrieved from https://www.who.int/nutrition/topics/glo baltargets_wasting_policybrief.pdf 
Jurnal Keperawatan Jiwa Volume 7 No 2 Hal 203 - 214, Agustus 2019

FIKKes Universitas Muhammadiyah Semarang bekerjasama dengan PPNI Jawa Tengah 